
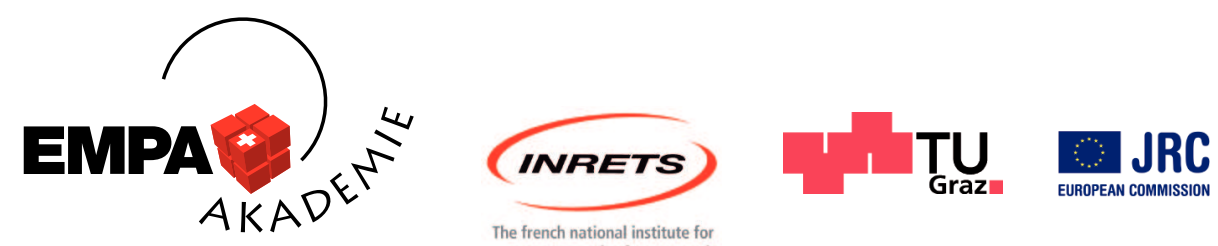

Zentrum für Wissenstransfer

$18^{\text {th }}$ International Symposium

\title{
Transport and Air Pollution
}

\section{Proceedings}

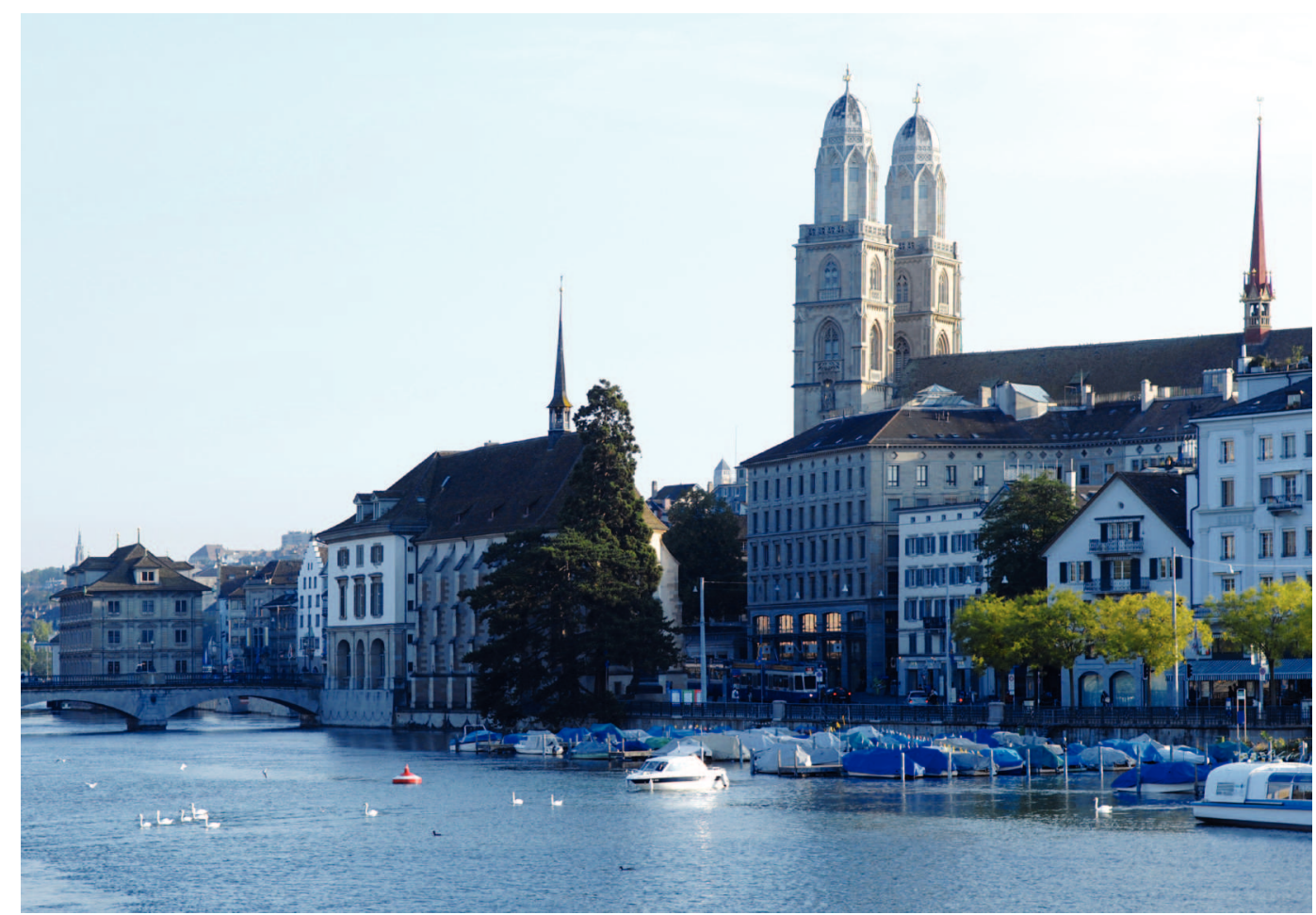

May 18-19, 2010

Dübendorf, Switzerland 
Scientific Committee

\begin{tabular}{|c|c|}
\hline $\begin{array}{l}\text { Martin Weilenmann } \\
\text { (Chairman) }\end{array}$ & Empa, Switzerland \\
\hline Michel André & Inrets, France \\
\hline Menouer Boughedaoui & Université de Blida, Algeria \\
\hline Brigitte Buchmann & Empa, Switzerland \\
\hline Aurélie Charron & Inrets, France \\
\hline Panagiota Dilara & EC-DG JRC, Italy \\
\hline Asif Faiz & The World Bank, USA \\
\hline Alan W. Gertler & Desert Research Institute, USA \\
\hline Roy M. Harrison & University of Birmingham, UK \\
\hline Stefan Hausberger & TU-Graz, Austria \\
\hline Robert Joumard & Inrets, France \\
\hline Mario Keller & INFRAS, Switzerland \\
\hline Ian McCrae † & TRL, UK \\
\hline Zissis Samaras & Aristotle Univerity Thessaloniki, Greece \\
\hline Constantinos Sioutas & University of Southern California, USA \\
\hline Ake Sjödin & Swedish Environmental Research Institute, Sweden \\
\hline Johannes Stähelin & ETH, Switzerland \\
\hline Peter Sturm & TU-Graz, Austria \\
\hline Dimitris Tsinoglou & Exothermia SA, Greece \\
\hline
\end{tabular}

Editor

Dr Martin Weilenmann / Rosemarie Lacher

\section{Impressum}

Empa - Materials Science and Technology

Überlandstrasse 129

CH-8600 Dübendorf / Switzerland

\section{Publisher}

Empa

\section{Organisation}

Dr Martin Weilenmann

Rosemarie Lacher

Phone: +418234679

Fax: $\quad+418234044$

e-mail: tap@empa.ch

www.empa.ch/TAP2010 


\section{Preface}

Ladies and Gentlemen, Dear Participants,

Traffic emissions and air quality have been topics for several decades already. Many improvements were achieved by a better control of combustion and appropriate aftertreatment systems. These achievements however were beaten out to a certain extent by the grow of traffic and of vehicle size and weight, such that in many "hot spots" local air quality is not satisfactory and mostly these hot spots are close to urban areas, where people live and work.

In parallel the global warming became a central environmental problem and traffic as a major contributor of $\mathrm{CO}_{2}$ and other greenhouse gases is in focus in this discussion. On the side of impact this means that air quality research today shows two dimensions, the global one dealing with global warming, and the local one of polluting humans, animals, plants and soil. On the side of technology the researchers and car manufacturers are challenged by a variety of technologies and fuels all promising reduced greenhouse gas potential, for which engines and aftertreatment systems need to be developed to improve or at least keep the low unit emissions of the actual models.

All these open questions ask for new tools in measurement and simulation for two aspects: to understand the mechanisms that are not well known yet, as well as to develop the necessary technology on time. Thus, this field of traffic related air pollution will keep its actuality for the future.

The Transport and Air Pollution symposium provides a forum for a broad interdisciplinary research community for knowledge exchange at a scientific level. The French National Institute for Transport and Safety Research (INRETS), the Institute of Internal Combustion Engines and Thermodynamics at the University of Technology of Graz and formerly the National Centre of Air Pollution (NCAR) jointly organized the TAP conferences. Newly from this year on also Empa the Swiss research institute for Material Science \& Technology and the EU Joint Research Centre (JRC) of Ispra are in this team of organisers.

This conference is the $18^{\text {th }}$ in this Transport and Air Pollution series and we hope you will enjoy your visit to Zurich and Duebendorf. We hope that the conference will meet your expectations in promoting the scientific exchange, extending and strengthening of contacts.

The work of all contributing authors and the scientific committee is gratefully acknowledged. We also want to express special thanks to the staff organising this conference.

Christian Bach

Martin Weilenmann

Dübendorf, May 2010 


\section{Content}

SESSION 1: ROADSIDE AND TUNNEL STUDIES.......................................................

Real-Time Vehicle Emission Monitoring Along Roadsides............................................................. 5

U. Stelwagen, R. De Lange, N.E. Ligterink, G.A. Klunder, A. Bigazzi, J.H. Duyzer, J. Van Baalen,

R.T. Van Katwijk, M.C. Kruithof, S. van Ratingen, J.H. Weststrate, I.R. Wilmink

Speed Dependence of $\mathrm{NO}_{2} / \mathrm{NOx}$ Emission Ratio?

J. Thudium, R. Alvarez, M. Weilenmann

Emission factors for paved and unpaved roads - validation by tunnel and field measurements

P. J. Sturm, M. Henn and G. Bachler

Interaction between Road Pavement and Tyre Studs Cause Emission of Nanoparticles

M. Gustafsson, G. Blomqvist, A. Gudmundsson

SESSION 1: NON ROAD TRAFFIC EMISSIONS

ALSTOM Hybrid shunter locomotive 32

R. Hesnard \& J. Oostra

Remote Measurements of Ship Emissions: The SIRENAS-R Campaign

J. M. Balzani Lööv, B. Alfody, F. Lagler, J. Hjorth and A. Borowiak

PARALLEL MONITORING CAMPAINES IN AN INTERNATIONAL ROMANIAN AIRPORT

F. Popescu, I. Ionel, C. Talianu, I. Belegante

Ship Emissions Estimates based on AIS data

M. Winther, M.S. Plejdrup, J. Christensen, H.R. Olesen, T. Ellermann

SESSION 2: EMISSION MEASUREMENT .

Real-time Analysis of Aromatic Compounds in Vehicle Emissions by Resonance-enhanced Multiphoton Ionisation - Time-of-flight Mass Spectrometry (REMPI-TOFMS).

T. Adam, C. Astorga, G. Martini, A. Perujo, U. Manfredi, A. Krasenbrink, M. Sklorz, M.

Elsasser, R. Zimmermann

Particles emitted by 2- and 4-stroke engines: Aspects from chasing and test bench experiments 62

S. Weimer, R. Richter, C. Mohr, D. Schreiber, A.S.H. Prevot, M. Mohr, P. Dimopoulos Eggenschwiler

Investigations of Diesel Emissions with DPF+SCR in VERTdePN 68
J. Czerwinski, Y. Zimmerli, N. Heeb,
A. Mayer,
G. D'Urbano 
Tailpipe emissions from garbage trucks in the metropolitan area of Milan, Italy and their evolution by 2010

P. Dilara, C. Pastorello, G. Martini, P. Bonnel, U. Manfredi

SESSION 2: AIR QUALITY MEASUREMENT AND MODELLING 80

Size resolved ultra fine particle model for a traffic tunnel

B. De Maerschalck, I. Nikolova, S. Jannssen, P. Vos

Impact of roadside noise barriers on particle size distributions and pollutants concentrations near freeways

Zhi Ning, Neelakshi Hudda, Nancy Daher, Winnie Kam, Jo rn Herner, Kathleen Kozawa, Steven

Mara, Constantinos Sioutas

$\mathrm{CO}_{2}$ Distribution and Transport in Urban Areas - A Task for High Resolution Urban CFD

A. Gartmann, M.D. Müller, R. Vogt, E. Parlow

Modelling Estimation of the Contribution of the Road Transport to the Particulate Matter Concentration over Italy

A Balzarini, G. Pirovano, G.M. Riva, A.M. Toppetti

SESSION 3: ELECTRO AND HYBRID VEHICLES

Foresight of Electrictransport in France: an opportunity with a smart demand side management ....107 Eric Vidalenc

Electric vehicle and plug-in hybrid energy efficiency and life cycle emissions.

H. Helms, M. Pehnt, U. Lambrecht and A. Liebich

Life Cycle Assessment of Battery Electric and Internal Combustion Engine Drivetrains for a Small Passenger Car.

A. Simons and C. Bauer

Effect of Battery Performance on Determining $\mathrm{CO}_{2}$ Emissions of Hybrid Electric Vehicles under Real-

World Conditions

Robert Alvarez, Peter Schlienger, Martin Weilenmann

SESSION 3: SECONDARY POLLUTANTS AND EXPOSURE

Long-term trend of direct $\mathrm{NO}_{2}$ emissions from urban road traffic in Zurich, Switzerland

Ch. Hueglin, Juerg Brunner, B. Bu chmann

City-dwellers exposure to atmospheric pollutants when commuting in Paris urban area

H. Ravelomanantsoa, Y. Le Moullec, C. Delaunay,G. Goupil, S. Mazoué

Modeling of Exposure to Highway Traffic Exhaust in Alpine Valleys in Switzerland.

R. Ducret-Stich, HC. Phuleria, M. Ragettli, A. Ineichen, C. Schindler, L.-J.S. Liu 
Performance of Clean City Bus Technologies in Real World Traffic

S. Hausberger, W. Stadlhofer, J. Blassnegger, M. Rexeis, A. Flanschger

Emissions Control Systems and Climate Change Emissions

J. May, D. Bosteels and C. Favre

Investigation of guanidinium formate as novel ammonia precursor compound for selective catalytic reduction of $\mathrm{NO}_{x}$

D. Peitz, O. Kröcher, M. Elsener

Combustion of mineral diesel and alternative fuels in a heavy duty on-road engine with combined $\mathrm{NO}_{\mathrm{x}}$ and particle exhaust gas treatment

P. Soltic, D. Edenhauser, T. Thurnheer, D. Schreiber, A. Sankowski

SESSION 4: EMISSION POLICIES

Effects of GHG-certificate trade on transport demand in Austria.

C. Link, J. Stark, R. Hoessinger, G. Sammer, G. Maier, J. Lechner, A. Sonntag

Air Quality Impact Assessment of the Environmental Zone in Copenhagen

S.S. Jensen, M. Ketzel, J.K. Nøjgaard, P. Wåhlin

$\mathrm{CO}_{2}$ Emissions and Daily Mobility: Factors for Change the Case of the Lyon Urban Area.

Louafi Bouzouina, Jean -Pierre Nicolas, Florian Vanco

SESSION 5: EMISSION MODELLING 1

Development and Evaluation of a Generalised Model for Traffic Induced Road Dust .205

J. Berger and B. Denby

Potentials and Costs for GHG Mitigation in the Transport Sector.

J. Borken-Kleefeld, J. Cofala, P. Rafaj, F. Wagner and M. Amann

SESSION 5: BIOFUELS 1

Experimental evaluation of straight vegetable oil-diesel blends application on vehicle regulated and non-regulated exhaust emissions over legislated and real world driving cycles

Georgios Fontaras, Marina Kousoulidou, Georgios Karavalakis，Stamoulis Stournas and Zissis

Samaras

The Impact of Biodiesel Blends on Emissions

Curt Robbins, S. Kent Hoekman, Amber Broch, Mani Natarajan and Alan Gertler 
SESSION 6: EMISSION MODELLING 2 ...................................................................... 230

Uncertainty and Sensitivity Analysis of COPERT 4

L. Ntziachristos, I. Kioutsioukis, C. Kouridis, D. Gkatzoflias, Z. Samaras, P. Dilara

Coupling of microscale traffic and emission models to minimize emissions by traffic control systems

M. Zallinger, R.Luz, S. Hausberger, K. Hirschmann and M. Fellendorf

Speed-time profiles as a basis for emission modelling of road traffic - the example of Munich

R. Gerike and F. Hülsmann

SESSION 6: BIOFUELS 2

Carbonyl compounds in exhaust from alternative fuels used in modern engines and from two stroke mopeds.

C. Astorga, M. Clairotte, T. Adam, A. Farfaletti, G. Martini

Determination of VOC components in the exhaust of light vehicles fuelled with different biofuels...260

F. Cazier, A. Delbende, H. Nouali , B. Hanoune, D. Pillot, R.Vidon, P. Perret and

P. Tassel

Emissions and fuel consumption of modern flexifuel and gasoline vehicles on various ethanol blends

L. Pelkmans, G. Lenaers, J. Bruyninx, I. De Vlieger 